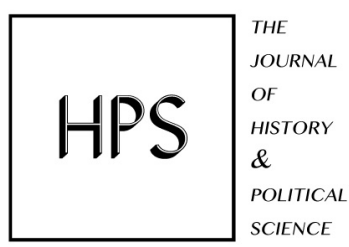

\title{
"Comme des bons pères de famille:" Masculinity, Patriarchy, and the Transnational Violences of Slavery in French Colonial North America
}

\author{
HPS: The Journal of \\ History \& Political \\ Science \\ 2017, Vol. 5 41-50 \\ (C) The Author(s) 2017
}

\section{Lauren Laframboise}

McGill University, Canada

\begin{abstract}
French colonial Louisiana has long captured the imaginations of academic and amateur historians alike. However, the histories of French Louisiana and New Orleans have often been analyzed within the canon of American history, overlooking its transnational and transcontinental connections to New France and the French Empire. This paper mobilizes $18^{\text {th }}$ Century court documents from French colonial New Orleans that detail an assault perpetrated by a plantation overseer against enslaved workers. Jacques Charpentier dit le Roy migrated to Louisiana from what is now known as Canada, and was employed as an overseer by plantation owner and Superior Council member Amyault d'Auseville. Charpentier's violent conduct led to the death of an enslaved man by the name of Brunet, and perpetrated multiple physical and sexual assaults against enslaved women, including Brunet's wife, Bizao. The d'Auseville vs. Charpentier case not only illustrates the violence of slavery within the French Empire, but also the ways in which class differences were mobilized to entrench racial hierarchies. Above all, the case shows that the institution of slavery was sustained by migrations within the French Empire in North America, and provides concrete evidence of the transnational and transcontinental nature of slaveholding. This paper problematizes historiographical arguments that slavery was 'less brutal' in the French Empire by bringing the d'Auseville vs. Charpentier case in conversation with the Codes Noirs and its patriarchal foundations.
\end{abstract}

\section{Introduction}

The histories of Louisiana, Canada, and the West Indies are deeply intertwined in their overarching connections to the French Empire. Often treated separately, these regions are 
characterized by common histories of colonization, racialized dispossession and forced migration. These narratives are brought in evidence when we consider the intersections of French colonial governance with the transatlantic slave trade. Against this backdrop, this paper analyzes an $18^{\text {th }}$ century court case related to the mistreatment of slaves by a Canadian plantation overseer in New Orleans, and the drama that ensued from the accusations. The d'Auseville vs. Charpentier case provides insight into the transcontinental construction of the French empire, and that the policing of slave labour in the South was maintained by internal migrations within New France between what is now known as Canada and the United States. It also sheds light on the institution of slavery in Louisiana, the nature of legal proceedings, and constructions of gender, sexuality and race. The court documents reveal that French colonial Louisiana was a veritable slave society; deconstructing and nuancing arguments that enslaved people were 'better treated' under the French regime. ${ }^{1}$

Legal practices in New Orleans regarding the enslaved and slave-owners were largely discretionary, as will be argued later in this paper, and left little mark on the archival landscape. Of the few cases that were recorded, most of the original documents are poorly preserved. Shannon Lee Dawdy notes that this is a classic feature of the French colonial Louisianan archive: documents require much patching together, and are strewn with gaps and silences. ${ }^{2}$ However, the Louisiana Historical Society has transcribed and translated summarized versions of what could be read from the primary sources, and published them in the Louisiana Historical Quarterly. To construct the narrative of this case, I have gone through the petty theft incidents, property settlements, and estate cases in volumes four and five of the journal, selecting relevant entries to the d'Auseville vs Charpentier case. These findings are outlined in Appendix I, presented in chronological order to follow the progression of the case. Unfortunately, the original documents are not accessible to the public, meaning that these translated summaries represent the only primary source pertaining to this case. The documents were subject to the interpretation of transcriptionist in the summaries, and went through the additional filter of translation from French to English. However, there is enough information to construct an approximate historical narrative behind what occurred between Amyault d'Auseville, an influential plantation owner and member of the Superior Council, and the Canadian plantation overseer he employed, Jacques Charpentier dit Le Roy.

\section{The Case: An Historical Narrative}

Court records for the d'Auseville vs. Charpentier case begin in January 1730 with the examination of the "delinquent steward," where he is brought before the Council on charges of "fraudulent management, cruelty of slaves, and the suspicious death of one or more of them," to which he "professes ignorance." 3 A few months later, a surgeon by the name of de Manadé writes a complaint letter regarding "obnoxious acts" committed by Charpentier, and "admits that he does not suit 'those Canadian gentlemen'." This complaint is then followed by an arraignment written by Councillor d'Auseville himself, calling Charpentier to court. d'Auseville outlines the various charges laid against Charpentier, including forced abortion and sexual assault toward enslaved women, violating the Code Noir by forcing work on Sundays, and stinting slaves of food. Then, another few months later, a coroner's 
report on one of d'Auseville's slaves, named Brunet, attributed the cause of death to suspicious circumstances. In September, a petition to prosecute Charpentier is drafted for the above-mentioned charges, and admits 'negroes' to the criminal proceedings. There is then another petition to reinforce the prosecution after Charpentier beat a slave woman named Bizao, Brunet's wife, to take revenge on the deceased man. This is when Charpentier claims immunity to the accusations, because his contract had "no provision holding him for damages as regards injured slaves," and testimonies provide meagre evidence. ${ }^{5}$ The records after this are somewhat inconclusive, but additional research has shown that the accused's contract was terminated, and sued 20,000 francs for damages to property. ${ }^{6}$ However, it is unlikely that Charpentier, a man of middling status, would have been able to pay such a considerable sum, so it is ambiguous as to whether or not charges were enforced. The case records end rather abruptly, with the possibility that d'Auseville and Charpentier reached an out of court settlement. ${ }^{7}$

\section{Case Analysis}

In this section, I will be drawing on the events that led up to, and took place during the unfolding of the d'Auseville vs Charpentier slave abuse case. From these court proceedings, we can raise questions about the nature of the legal system in New Orleans, the motivations behind the Code Noir of 1724, and the selectiveness of its enforcement. It also shows the mechanics of New Orleans society, from gender dynamics, to the paramountcy of the institution of slavery, to important questions of racial ideology. First, the dynamism of law in French Colonial New Orleans will be examined in order to contextualize the court proceedings and their results.

\section{Law in New Orleans}

French colonial New Orleans had a complex, codified legal system that conducted effective, yet selective court proceedings. Post-Mississippi Bubble, New Orleans saw a considerable drop in European immigration, leading to the creolization of European populations. ${ }^{8}$ There were a limited number of men from France with proper social stature and education to fill Superior Council slots: councillors-at-large were thus chosen from the wealthiest and most influential class, the local planter-merchants. ${ }^{9}$ By the 1730 s, around the time of the d'Auseville vs. Charpentier case, local interests began to take precedence over the word-forword enforcement of the law, focusing their energy on the effective control of the enslaved. According to Shannon Dawdy, the "councillors deeply invested in slaveholding took it upon themselves to promulgate laws and reshape legal practices, a privilege usually reserved for the King." 10 Therefore, the creolization of the council led to a serious dwindling of the King's power in the French New Orleans colony. As the justice system began shifting from the interests of the French metropole to those of the local slave-owners dominating the Superior Council, the latter sought to enforce their own rising status and defend their domination over property.

Another relevant trend in the city of New Orleans was an increase in violent crime in the period of 1727 to 1747. It was French men of middling status who committed one-third of all reported homicides, a statistic that was disproportionate for their small numbers. ${ }^{11}$ 
Charpentier had leased d'Auseville's property just downriver from New Orleans, showing that he did not have enough wealth to own a plantation or slaves, making him part of this particularly violent category. ${ }^{12}$ This rise in violence is certainly in accordance with increasing concerns for maintaining control over the growing slave population. In fact, between 1719 and 1731, almost six thousand Africans were brought to Louisiana, dwarfing its European population. ${ }^{13}$ These developments had serious implications for the legal system, leading to the introduction of the Code Noir of 1724.

\section{The Code Noir of 1724}

The Code Noir of 1724 was revised from the French West Indies' Code Noir of 1685 to create a slave society different from that of Saint-Domingue, directly intervening in masterslave relationships. These new revisions limited corporal punishment, as Saint-Domingue officials worried that an escalation of violence and abuse committed by individual slaveowners and managers threatened to destabilize the institution of slavery. In 55 articles, the Code Noir of 1724 urged colonists to instruct, baptize, clothe, and feed their slaves. It formally defined the enslaved as "movable property," restricting their movement, property ownership, and ability to testify against their masters and overseers. Slave-owners were required to treat their slaves "comme des bons perres de famille", ${ }_{14}^{14}$ as the torture, maiming, and execution of slaves remained the responsibility of colonial judges. Thus, masters were prohibited from directly administering any of the more severe punishments. However, this changed over time. With the entrenchment of the plantation system and the creolization of the New Orleans population, the discipline of slaves became an increasingly private matter, only to be settled between plantation owners, overseers, and the enslaved. ${ }^{15}$

Code Noir violations were subject to prosecution by the Superior Council, but they followed an extremely selective enforcement policy, exempting many of such criminals from trial. Compliance was largely voluntary; provisions that were deemed to help the efficient management of slaves were obeyed, whereas the more restrictive and impractical were ignored. The prosecution of acts of cruelty toward slaves were confined almost exclusively to overseers or lessees, never the slave-owners themselves. In reality, the treatment of the enslaved and the material conditions in which they lived were governed by the changing fortunes of plantation agriculture. ${ }^{16}$

\section{A Veritable Slave Society}

New Orleans is highly exemplary of what is defined as a slave society, in which the institution of slavery permeates all social relations as colonial officials took great care to maintain the fragile balance between races. ${ }^{17}$ Using forms of interracial punishment not only in the form of white on black violence, but also using manumitted Africans to punish white criminals, the state maintained animosity between the segments of the population as part of a calculated "divide and rule" tactic. ${ }^{18}$ The definition of enslaved human beings as property is perhaps the most dehumanizing aspect of a slave society, and can be seen in nearly all of the court documents. Suits involving the criminal maiming of the enslaved were exclusively civil, the owner attempting to recover the value of his damaged property from the defendant. In fact, very close parallels can be drawn from cases of damages to livestock those of slave abuse. In the d'Auseville vs. Charpentier case, there is repeated mention of animals within the descriptions of Charpentier's abuses, showing the degree to which enslaved people were conceptualized as movable property ${ }^{20}$ Given these realities, the 
Superior Council members' motivations behind the enforcement of the Code Noir and their conceptualization of the enslaved as property become increasingly clear.

\section{Masculinity, Class, and Sexuality}

Expressions of masculinity, class, and sexuality can also be found in the d'Auseville vs Charpentier case, and are often reasons for which abuses toward the enslaved were committed. Old World notions of honour were extremely prevalent in New Orleans society. ${ }^{21}$ Because land tenure was not seigneurial, like in other parts of New France, slave ownership was an important source of prestige..$^{22}$ The slave-owning class was a product of an exceedingly patriarchal society, channelling masculinity under the prerogative of 'guiding' and 'disciplining' their workers. ${ }^{23}$ The Code Noir urged masters to be good family fathers, ${ }^{24}$ and this paternalistic mindset can be seen in much of the writings of its contemporaries. For example, in his chapter "The Manner of Governing Negroes," Le Page du Pratz explains: "When a negro man or woman comes home to you, it is proper to caress them, to give them something good to eat... those marks of humanity flatter them, and attach them to their masters." ${ }^{25}$ In this passage, the true motivations behind providing for slaves' well-being are evident, showing a concern for only the efficient extraction of labour and the maintenance of the delicate balance of race relations. Though the gender imbalance tended to favour females in urban New Orleans, enslaved women living in French colonial Louisiana's rural areas faced violence unmatched elsewhere in the United States. ${ }^{26}$ Enslaved women had a particularly vulnerable position in society, and were repeat victims of sexual violence, as can be seen in the reports of Charpentier's constant advances on these women, even out in the open field. ${ }^{27}$ This kind of sexual exploitation was just one of the regular abuses of power and authority committed by slaveholders and overseers toward enslaved women.

\section{Old and New World Discussions on Race}

The above analysis of the d'Auseville vs. Charpentier case provides us with valuable information concerning the slave society that was New Orleans in 1730. It outlines the blatant brutality of the institution of slavery, yet it is often argued that slaveholding was less brutal on French colonial soil compared to the rest of the United States. In his article regarding the Transatlantic origins of the Code Noir, Guillaume Aubert points out an exceedingly relevant and damaging trend in the historiography of Louisiana. He argues that historians of Louisiana have generally been unwilling to view the Code Noir as an expression of racial ideology, stemming from the Code's order to instruct and baptize their slaves, which promoted the "right" for enslaved Africans to become members of the Christian community. However, article 2 of the Code Noir, requiring settlers to have their slaves baptized and instructed into Catholicism, was not only largely ignored, ${ }^{28}$ but also served to reinforce rather than undermine racial hierarchies. ${ }^{29}$ Aubert's argument goes further to say that slaves were provided legal protection and spiritual entitlement, setting French Louisiana apart from 'harsher' British slave regimes.

Not only are these views extremely detrimental to historical conceptions of slavery in the United States, but they also separate the Code Noir from its French metropolitan origins and their constructions of race. The Code Noir is imbued with colonial ideas of a direct connection between African ancestry, perpetual servitude, and social inferiority. ${ }^{30}$ This is obvious in Article 6 of the Code, which strictly forbade intermarriage between blacks and 
whites due to concerns over the "mixing of blood" ${ }^{31}$ showing a desire to preserve the 'purity' of French blood in the colony and implying their superiority over the black population. French metropolitan constructions of race lasted into the mid $18^{\text {th }}$ century, which can be seen in French navy captain Jean Bernard Bossu's travel writings: "black, tanned, and red slave women have corrupted blood... disastrous to the propagation of the human species." 32

\title{
Concluding Remarks
}

The importance of historiography and its influence on today's perceptions of slavery quickly came to the forefront of this project. As Aubert argues in To Establish One Law and Definite Rules, American historians of Louisiana have systematically negated the experience of slaves in the French colonial South by failing to recognize the inherent racialism of the Code Noir, and the extent to which brutal violence was committed against black bodies in the French colonial era. Even though Carl Brasseaux's article provided valuable information on the administration of the Code Noir, he is certainly one of the American historians painting an unrealistic picture of plantation owner benevolence toward slaves. He cites many cases of supposed "voluntary' humane treatments of the enslaved, where they were cared for 'as he would his children." ${ }^{33}$ However, the court case examined in this paper, along with the nature of the Code Noir, reveals the purely utilitarian and deeply racialist mindsets of slaveowners and overseers in French Colonial Louisiana.

Owing to the nature of French colonial archival practices, an analysis of the d'Auseville vs Charpentier case has proven to entail some methodological challenges but nevertheless offers a considerable amount of insight into the nature of the relationship between the institution of slavery and French Colonial New Orleans. More importantly, however, this case is part of a greater narrative of the legacies of slavery in the United States, and its deep transatlantic connections to the French empire. Though France had abolished slavery within its state, the legal ambiguities regarding slavery in the colonies was a contributing factor to racialized violence at astronomical levels. The migration of Charpentier and his identification as a "Canadian" also indicates longstanding connections between the French colonies, and shows that the violence of colonization extends across the settler colonial nations of North America.

\section{APPENDIX}

\section{Relevant Entries to the d'Auseville vs Charpentier case}

\author{
Source $A^{34}$
}

p. 510. January 17, 1730: Examination of a Delinquent Steward

Jacques Charpentier, alias Le Roy, steward of Amyault d'Auseville, is overhauled before Councillor Prat on charges of fraudulent management, cruelty to slaves, and the suspicious 
death of one or more of them. His answers generally deny the charges, and he also professes ignorance in many articles.

Possibly this document is incomplete, as there is no formal conclusion. Snakes, incidentally, are mentioned as destroying pigeons, and weasles the poultry.

p. 518. April 6, 1730: Letter of de Manade to d'Auseville

Complaining, in very illiterate script for a surgeon, of obnoxious acts on the part of one Roy. The writer admits that he does not suit 'those Canadian gentlemen.' He would avoid all dealings with Roy, and means to ask the 'Religious Ladies' to send their sick slaves to town, where the surgeons will attend to them and leave fees to the Nuns' discretion. (Roy, presumably, was an overseer).

Rent in last page.

p.521. April 22, 1730: Remonstrance

Councillor Amyault d'Auseville argues forcibly and virtuously away from the main issue, but leaves that untouched, namely, that Buquoy's slave is unfit for service, and should therefore be returned. Councillor D'A. seems to imply B. took his chances, and ought to bear consequence. (It rather strengthens B.'s case for the Councillor to admit that B. has offered him 20 quarters of rice if he would take back the negro.) Let B. be non-suited.

No note by court.

p.521. April 29, 1730: 'To Sieur Roy'

A severe arraignment, apparently in the writing of Councillor Amyault d'Auseville, of his brutish overseer. A main charge is that of causing frequent abortion among the slave women by corporeal punishment in pregnancy. There is also the damaging insinuation that Roy is especially vindictive to those women slaves who repel his lust in the open field. Again, Roy slights the Black Code in its prohibition of Sunday taskwork, and he stints the slaves of necessary provisions. He is also unsparing of horse life. Send the rest of threshed rice.

Writer forwards six bags marked AD.

\section{Source $B^{35}$}

p. 87. August 7, 1730. Surgeon's report.

Dr. Jean de Reytet submits a minutely detailed report of his post mortem examination of a negro named Brunet, belonging to Councillor d'Auseville. Marks of gangrene about the cavity otherwise known as the ventricule. An intestinal worm discovered, ten inches long, armed with a 'dart'. Gall duct void of bile. (Gangrene seems to have ensued from a bruise and confined blood clot.)

Well written

p.91. Sept. 5, 1730. Petition to prosecute scoundrel overseer.

Councillor Amyault d'Auseville supplements his earlier charges against Jacques Charpentier alias le Roy with especial stress on the overseer's fool cruelty (senseless no less than devilish) in the direction of starving the cattle, exhausting the slaves by long hours and vile fare (one 
meal of rotten beans a day), and causing continual abortions. But the overseer is cunning no less than brutish, and manages to conceal most of his crimes from white witnesses. Let negroes also be admitted to the trial proceedings.

p. 91. Sept. 5, 1730. d'Auseville vs. Charpentier (Le Roy)

Giving the devil his due, Council orders that the accused Le Roy be heard and examined.

N. B. - The scribbler of these cards came from a northern state, and possibly retains a traditional Union bias towards slavery. But the charges of brutality in this case and others among the French records of Louisiana Province are adduced by an acclimated slave owner, speaking right from the spot and core of that abolished 'institution'.

p. 92. Sept. 5, 1730. d'Auseville vs. Charpentier alias Le Roy.

Charpentier shall first be heard and examined.

p. 92. Sept. 7, 1730. Petition to reinforce prosecution

Councillor Amyault d'Auseville reports that Charpentier has taken revenge on the negro Brunet's account by beating Bizao, Brunet's wife, on the head and breast with closed fists. The overseer feels himself the more immune because in his contract of lease there was no provision holding him for damages as regards injured slaves. Let the petitioner's negroes be heard as witnesses.

Approved: Prat.

p. 94. Sept. 18, 1730. Testimony on Overseer Charpentier.

Very meagre evidence from witnesses Albert Bonne, Anne Coudret, wife of Jean Baptiste Leonard and Surgeon Pierre de Manadé. A. B. heard 'early ringing;' Anne C. sustains charge of hungry cattle, and the surgeon felt obliged to report the overseer to Councillor d'Auseville for striking a negro with an axe handle.

Attorney General orders hearing of Charpentier.

p. 104. Dec. 1, 1730. Remonstrance.

Councillor d'Auseville reviews one by one the demands of his tenant Roy (whose lease is to expire on Dec. 31). And riddles them with every appearance of reasonable warrant. The roofing plea was obtruded by Roy in collusion with Vien, and must wait till Vien affair be settled. Roy's plantation claims didge the counter charges already pending against his brutality (even yet Persistent) and wastefulness. Accurate accounting is in process, but cannot be forestalled by premature assumptions on Roy's part. Nonsuit Roy and hold him to terms of satisfaction point for point.

Approved for action.

Prat.

p.104. Dec 2, 1730. Decisions in Sundry Suits

Roy vs d'Auseville. Shingling must wait until other matters be set clear. R. nonsuited in plantation claims (rice and sow). 


\section{NOTES}

${ }^{1}$ For an example of this argument see Guillaume Aubert, "'To Establish One Law and Definite Rules': Race, Religion, and the Transatlantic Origins If the Louisiana Code Noir," in Louisiana: Crossroads of the Atlantic World, ed. Cécile Vidal, 21-43, (Philadelphia: University of Pennsylvania Press, 2014).

${ }^{2}$ Shannon Lee Dawdy, Building the Devil's Empire: French Colonial New Orleans, (Chicago and London: Chicago University Press, 2008), 207.

${ }^{3}$ See Appendix I. John Dymond, Henry Plaucher Dart, The Louisiana Historical Quarterly, Vol. 4, (New Orleans, LA: The Louisiana Historical Society, 1921), 510.

${ }^{4}$ Ibid., 518.

${ }^{5}$ See Appendix I Henry P. Dart, The Louisiana Historical Quarterly, Vol. 5, (New Orleans, LA: The Louisiana Historical Society, 1922), 92.

${ }^{6}$ G.C. Din, Spaniards, Planters, and Slaves: The Spanish Regulation of Slavery in Louisiana, 1763-1803, (Texas: A\&M University Press, 1999), 15.

${ }^{7}$ Ibid., 15.

${ }^{8}$ Catherine Desbarats, "French Louisiana," lecture for HIST 334: History of New France, McGill University, Montreal, QC, March 9, 2015.

${ }^{9}$ Dawdy, Building the Devil's Empire, 195.

${ }^{10}$ Ibid., 194.

${ }^{11}$ Ibid., 214.

12 J.M. Spear, Race, Sex, and Social Order in Early New Orleans, (Baltimore: Johns Hopkins University Press, 2010), 72.

${ }^{13}$ Patrick G. Williams, S. Charles Bolton, and Jeannie M. Whayne, eds., Whole Country in Commotion: The Louisiana Purchase \& the American Southwest, (Arkansas: University of Arkansas Press, 2005), 108.

${ }^{14}$ This refers to the Roman legal concept of bonus pater familias, or the good family father. It is the predecessor of the 'reasonable person' in English law. See Wendy Parker, "The Reasonable Person: A Gendered Concept," Victoria University of Wellington Law Review 23.2 (1993): 105-112.

Le Code Noir Ou Édit Du Roi, Touchant L'état Et La Discipline Des Esclaves Nègres De La Louisiane. Louis XV. Versailles, 1724. Article 49.

${ }^{15}$ Carl A. Brasseaux, "The Administration of Slave Regulations in French Louisiana, 1724-1766," Louisiana History: The Journal of the Louisiana Historical Association 21, no. 2 (1980): 149.

${ }^{16}$ Williams, Bolton, and Whayne, Whole Country in Commotion, 109.

${ }^{17}$ Desbarats, "French Louisiana."

${ }^{18}$ Dawdy, Building the Devil's Empire, 200.

${ }^{20}$ See Appendix I: April 29, 1730; September 5, 1730; September 18, 1730.

${ }^{21}$ Dawdy, Building the Devil's Empire, 214.

${ }^{22}$ Desbarats, "French Louisiana."

${ }^{23}$ Brasseaux, "The Administration of Slave Regulations in French Louisiana," 140.

${ }^{24}$ Le Code Noir Ou Édit Du Roi, Article 49.

${ }^{25}$ Du Pratz, Le Page, "Of the Negroes of Louisiana." Chap. IV In The History of Louisiana or of the Western Parts of Virginia and Carolina: Containing a Description of the Countries That Lie on Both Sides of the River Missisippi: [Sic] with an Account of the Settlements ... Translated from the French of M. Le Page Du Pratz; with Some Notes and Observations. (London: Printed for T. Becket, 1774), 380.

${ }^{26}$ Catherine Clinton and Michele Gillespie, The Devil's Lane: Sex and Race in the Early South, (New York: Oxford University Press, 1997), 256.

${ }^{27}$ See Appendix: April 29, 1730. 
${ }^{28}$ Brasseaux, "The Administration of Slave Regulations in French Louisiana," 148.

${ }^{29}$ Guillaume Aubert, "'To Establish One Law and Definite Rules': Race, Religion, and the Transatlantic Origins If the Louisiana Code Noir," Chap. 1 In Louisiana : Crossroads of the Atlantic World, edited by Cécile Vidal, 21-43. (Philadelphia: University of Pennsylvania Press, 2014), 42.

${ }^{30}$ Ibid, 23.

${ }^{31}$ My translation from the original French, "mélange de sang." Le Code Noir Ou Édit Du Roi, Article 6.

${ }^{32}$ Jean Bernard Bossu, Nouveaux Voyages Aux Indes Occidentales Contenant Une Relation Des Differens Peuples Qui Habitent Les Environs Du Grand Fleuve Saint-Louis, Appellè Vulgairement Le Mississippi : Leur Religion : Leur Gouvernement : Leurs Moeurs : Leurs Guerres \& Leur Commerce, Vol. 1, (Paris: Chez Le Jay, 1768), 201.

${ }^{33}$ Brasseaux, "The Administration of Slave Regulations in French Louisiana," 140.

${ }^{34}$ John Dymond, Henry Plaucher Dart, The Louisiana Historical Quarterly, Vol. 4, (New Orleans, LA: The Louisiana Historical Society, 1921).

${ }^{35}$ Henry P. Dart, The Louisiana Historical Quarterly, Vol. 5, (New Orleans, LA: The Louisiana Historical Society, 1922). 